\title{
The Dissemination Strategy of the British National Image in China from the Public Account of "UK Now"
}

\author{
Xinrui Li \\ School of Arts and Media \\ Sichuan Agricultural University \\ Ya'an, China
}

\begin{abstract}
The continuous development of new media technologies has resulted in a diversity of communication methods and a wider range of communication. When communicating with new media, the multi-angle dissemination of national image should first consider the multiple dimensions that influence the national image. While the "UK Now" spreads the image of the British nation, although the content focuses on the "art", it involves many dimensions of the country's image, including many aspects, such as the related cultural image, urban image, historical image, national quality, and government image and so on. In the new media environment, the dissemination of national image should fully consider the characteristics of the target of dissemination; make rational use of emerging media resources, and advance with the times. Therefore, how to formulate reasonable communication strategy and enhance the reputation of the country is of great strategic significance to the spread of national image.
\end{abstract}

Keywords-WeChat public account; contents; SI-UK Education Council; national image; dissemination strategy

\section{INTRODUCTION}

The shaping and dissemination of national image is of great significance to the development of the whole country. As the earliest industrialized country in history, Britain has long recognized the necessity of national image to enhance cultural soft power. In the image building and cultural transmission of its own country, SI-UK Education Council has been playing an indispensable role. Since its establishment in 1934, the association has been growing and attracting worldwide attention and input. The association has long attached great importance to cooperation with China, aiming at spreading its own culture through the humanities, academic and media levels, and setting up a charismatic British national image. At the same time, with the continuous innovation of media technology, the media environment has changed. The impact of new media, such as WeChat and micro-blog, on the traditional media, makes the boundaries of the traditional media dispel, and then creates a driving force for shaping the country image.

\section{The MEANING OF THE NATIONAL IMAGE}

On the so-called national image, the American political scientist Boulding, K.E. thinks that: "The National Image is a combination of a country's perception of itself and other actors in the international system." ${ }^{(1)}$ Domestic scholar, Zhang Yuqiang, from the perspective of communication studies, believes that the national image is "information output of a sovereign country during the course of system movement by a public medium under specific conditions after being publicly imaged." (2) And Liu Xiaoyan's view of the national image refers to the "the reflection of the country's objective image in public's opinion" and is a "comprehensive reflection of the public's impressions, opinions, attitudes, and evaluations of the country, and the sum of the public's emotions and will of the country." ${ }^{(3)}$ Cheng Manli believes that the national image means " it is generated by being extracted and refined on the basis of historical and cultural traditions and the integration of the modernization elements" and it accumulates "the glittering points of the country's or national spirit". ${ }^{(4)}$

\section{III. "MULTIDIMENSIONAL MOLDING" OF THE NATIONAL IMAGE}

Because of the various viewpoints of "multi-dimensional molding" of the national image in the academic circles, this paper mainly refers to the important dimensions of the state image put forward by the national scholar Fan Hong, that is, "the identity of the national image, the introduction of the state context, the image of the government, the image of the enterprise, the city image, the historical image, the cultural image and the quality of the national" ${ }^{(5)}$. An analysis will be made in combination with of the shaping and dissemination of the British national image in the "UK Now".

\section{THE BRITISH NATIONAL IMAGE IN THE "UK NOW"}

\section{A. The Basis of the Lasswell 5W Model}

Based on Lasswell's 5W model, this paper regards the dissemination content, namely the content construction as the main body to analyze and carries out auxiliary analysis based on the communication environment, namely the platform 
environment and the dissemination object of WeChat in the light of communicator, namely organization control.

\section{1) Organization control}

a) "UK Now": "UK Now" is an online platform for culture and art launched by the British Council. Its name is same as a grand meeting for the art and creative industries conducted from April to November in 2012, which was held by British to celebrate the 40th anniversary of the establishment of ambassadorial diplomatic relations between Britain and China. The difference lies that the current "UK Now" is a platform for cultural exchanges in China for a long time belong to British Council. The WeChat Subscription was founded in 2015, and it goes into the British Council.

b) The nature of the British Council: The British Council position itself as an international institution to provide educational opportunities and promote cultural exchanges in the UK. It was established in 1934 as a British Royal chartered non-profit organization and a British public institution. By this token, the British Council is regarded as a non-governmental organization, but according to the background of its establishment, there is a certain difference with other NGOs.

As for the composition of senior personnel of British Council, the foreign minister has the right to appoint a member of the board of directors in accordance with the provisions of the Royal Charter. The elected chairman and vice chairman of the board also need approval from the Minister of foreign affairs. As far as the source of funds is concerned, the British Council, in addition to the service income, also accepts some significant appropriations from the British government to achieve its independent operation. ${ }^{(6)}$ In view of this, the British Council has some official character. As a quasi official cultural organization, it represents the official image of the United Kingdom in great significance in the process of foreign communication, and through the projection of the official image, it conveys the national image of the country.

To sum up, the British Council, in essence, is in line with the official foreign affairs of the UK, representing official position to a great extent, and has long been committed to disseminating its image from many angles. As a disseminator, the British Council how to introduce the national situation to the outside world directly reflects the national image of Britain. In the field of art, the British Council aims to "promote the innovative and diversified essence of British art to China". In the field of education, it aims to "help Britain establish educational links with all countries in the world in order to improve the quality of education, to cultivate citizens of the world and to build international trust and understanding."In the field of social projects, it "aims at coping with social and environmental problems and building a more inclusive, sustainable and prosperous future for all."In this communication process, it is necessary to seize the psychological characteristics of the audience to create attractive topics, convey comprehensive, real and effective national information, and then, create a more favorable image of the country in a positive way.
Therefore, the spread of the "UK Now" in China is based on the main body of the British Council, which helps it a lot to lay a solid foundation for the communication in China by making full use of the high quality resources of foreign communications belong to organizations and the state, and the features of relative independence accompanied with certain official nature. It combines and utilizes the unique perspective of the new media platform to make the national image more diversified.

\section{2) Content construction}

a) The identification of "UK Now": The national identity is the text and visual symbol of the core spirit and complex connotation of the national image. ${ }^{(5)}$ Therefore, intuitively, the avatar of the public account is used as a symbol of the national image of the United Kingdom for dissemination.

In order to distinguish from the "UK NOW artistic description of Britain" held in China from April to November in 2012, the British Council "UK Now" representing the public identity of the national image is more refined and more conducive to communication. Different from the original logo that is established by the combination and deformation of six colors of Pope, blue and white porcelain veins of Chinese culture and the British flag, its brand new logo is based on the British symbolic red, with the white words of "UK NOW" and the "artistic description of British". The logo, as the identification of "UK Now", only uses red and white colors, similar to the famous weekly "Economist" for the international market, which has strong transmissibility .The whole logo, combined with the red complex of Britain, is concise and clear in the Wechat signal. At the same time, it conveys lively the royal dignity of the British imperial family and the national spirit of the enthusiasm, courage, positiveness and perseverance.

b) Block 1:"The Activity of Artistic Description": The content of the "UK Now" is divided into three major blocks, including "artistic description activity", "art column" and "artistic description recommendation", and the audience can choose the content according to their own preferences. This paper is based on the time from February 9, 2015 to April 28, 2018 to mainly analyzes the presentation of the national image in the three parts.

Culture, in its general sense, refers to the sum of material wealth and spiritual wealth created in the course of the development of human society. ${ }^{(7)}$ Culture is the soul of a nation. The image of culture is the most important part of the national image and its importance should not be underestimated. All along, Britain attaches great importance to the shaping and dissemination of its national cultural image throughout the world. At the same time, British culture is unique. The shaping of Britain cultural image is to spread the deep British culture through various cultural products to the whole world, thus getting the appreciation and even recognition of the people of different countries. As the focus of dissemination and creation of "UK Now", cultural image runs through the "Recommendations for the current month" column in the "Art Activities" section. Its content enables the Chinese audience to more deeply contact with British local culture and 
cultural products by presenting the current offline activities, thus more conducive to the spread of British cultural image. In the " Recommendations for the current month", there are 4 pieces in the public account platform in April 2018, mainly consisting of the British Theatre "The Curious Incident of the Dog in the Night-time" drama, the Tate Britain Museum of British Art and the Shanghai Museum as well as the "Art Beijing" Expo of British Council's participation, involved a wide range of cultural and artistic fields, including British dramas, British landscape paintings, British snake art galleries and other British outstanding cultural and art exhibitions in China.

From the volume of reading in April, the audience has the highest attention to the April 26, 2018 "the Landscape of the Mind: Collections Exhibition of the Tate Britain Art Museum (1700-1980) in the Shanghai Museum." From the content of this article, the tweet substance is very poetic to introduce the British landscape painting, the special exhibition of "the Landscape of the Mind" and the history of Tate, and it elaborates the relationship between them. The forms of expression mainly include text, pictures, moving pictures, and short videos, and are often presented in a variety of combinations such as text and pictures, text and GIF, etc., so that readers can better grasp the key points in the reading process, and are not easily tedious. As the deep connotation to be expressed in this tweet, "sublime" and "picturesque" are always imprinted in the minds of the British people while the "travel", "evolution" and "return" are descriptions and refinements of the historical and cultural changes in Britain in the past few centuries. When these unique British cultural connotations are integrated into the past landscapes, and at the same time, the cultural self-confidence of the United Kingdom in the three hundred years are elaborated in the form of unique visual symbols, a more profound and concise British national cultural image shall be successfully shaped. While moving people's hearts, it also makes the dissemination of national cultural image more valuable and meaningful.

c) Block 2: "Column Now": From the column index of "Column Now" of the second block, a total of four sections are divided on the basis of time, namely "British Art Online", "British Voice", "Artistic City", and "Female Now".

As for the molding and communication of a country's image, the importance of historical image can be understood without being told. The projection of country image is originated from the accumulation of its historical image to a large extent, so we should carry forward our own country's history with the vision of globalization and development while strengthening our own cultural confidence by virtue of historical and cultural heritage. Transfer our own country's historical culture into the symbols acceptable to the audiences on the basis of the above to arouse the audiences' interest, so as to promote better transmission of country image in the world. "British Art Online" is an online column opened based on WeChat Official Account Platform in 2016. There were ten weeks of demonstration from early March to May, 2016. An institution cooperated with the host British Council was brought out through the Official Account Platform each week. The British historical culture is carried inevitably in the longterm development process of these institutions, which is of profound historical cultural atmosphere, containing ten British institutions including Barbican Centre, The Welsh National Opera and National Galleries of Scotland. Moreover, the contents of the column are diversified and include video, audio, pictures, interactive online games and tests, aiming to express British unique culture with more interest, in order to mobilize audiences' participation from multiple perspectives and strengthen the relation between audiences and Britain.

As the power to enhance and develop the country image, national quality has affected country image's spreading in other countries to a large extent. Only by having good national quality, can a country gain favorable impression from other countries, can its national image index go up constantly, and can it win the respect and cultural identification from countries around the world. As the fourth "British Plan for Residing in China" in the period of April to the last ten-day of October 2017, "British Music" supported three British musicians, namely Emmy the Great, Quinta and David Lyttle, to come to different places of China, including Gulangyu Island of Xiamen, Guizhou and Suzhou, to carry out the music residing plan for a period of six weeks. By the presentation via Official Account Platform, they gave play to their music talent fully through the recreation of eastern and western cultural elements In addition, as the persons spreading British national quality directly in China, they presented the good national quality of British people to the masses of China.

As the important part for shaping national image, city image is helpful to the identification of this country's image by the outside world. The public's impression and view toward the city can be improved through creating good city image, and it can also be regarded as an important means to mold country image. "City Now" introduces nine cities of Britain from the aspects of "City Overview" and "Depth of the Story", and the cities include Liverpool, Sheffield, Edinburgh and London. In the "City Overview", the expression forms are still mainly the combination of video, pictures and words, containing the historical culture, glorious achievements and local customs and practices of the whole city. "Depth of the Story" aims at the excellent groups and organizations in the city to a larger extent and the contents are mainly presented through official question and the real answer of the interviewees, presenting the city image with more cultural connotation, city regional characteristics and identification.

In the column of "Female Now", as the whole-year project of British Council in 2018, "Future Elite, Female Now" aims to stimulate young females to explore the world of creativity, to seek for more possibilities, so as to speak for the females. However, it has only been carried out for one time within a short time, so the contents which can be explored from it are limited.

d) Block 3: "Recommendation Now": In the Block of "Recommendation Now", the columns include "Spirit of Youth", "Eternal Shakespeare" and others. The column of "Eternal Shakespeare" also pays attention to the construction of its cultural image, so the author mainly elaborates the "Spirit of Youth".

As another important part of country image, government image does not equal to country image directly. The 
international image of the government influences the country's image directly. Spirit of Youth is sponsored jointly by British Government, British Council and British Tourist Authority, and displayed through the WeChat Official Account Platform. The public support and good interaction of British Government toward "Spirit of Youth" reflects that British government pays attention to the next generation of leaders of China and Britain, and hopes to conduct deeper cooperation with China. From the molding of country image, the whole spreading process has shaped a positive and friendly British government with positive manners, and it is more conductive to the spreading of Britain image.

Online "Eternal Shakespeare" combines the works of Shakespeare and WeChat Official Account push, takes the film recommendation, short fill, and travel notes as contents, presents the British culture with unique attraction to the audiences on the 400th anniversary of Shakespeare's death, so as further promote the molding and spreading of British cultural image.

3) Spreading object: Theoretically, the spreading objects of WeChat Official Account "UK Now" are mainly the masses of China. However, with the arrival of self-media era, the multiple and fragmental information comes out increasingly. Obviously, WeChat Official Account can no longer win the general interest and satisfy the demands of most of the audiences. Therefore, only by aiming at the levelone audiences, namely the subdivided groups, can the WeChat Official Account give play to its role, can the spreading of information be meaningful. As a result, as the direct audiences of "UK Now" who keep a watchful eye on it, the section of subdivided audiences is the researching emphasis of spreading object.

The backstage data of WeChat Official Account can only be checked by the operator by logging in it due to its confidentiality. In order to understand the opinions and demands of users of WeChat Official Account "UK Now", the author selects the messages left by six users under different articles, so as to further understand the audiences' opinions and demands towards the information offered by Official Account.

In the Block of "Artistic City", the WeChat user "Ailei" pointed out "like the yard theater" in the article of "If you are board with London, you board with life"; WeChat user "Yulong" left message saying "how joyful arts festival and the cultural city Edinburgh of Scotland" in "Arts Festival and Cultural City, Edinburgh the Capital of Scotland"; in another article "Story of Theater City, Glasgow on Screen", the WeChat user "Azi" commented that "I watched Death Watch" in the Film House of Edinburgh several years ago, and the scene of city in this film left me deep impression. This is one of the science fiction films I like most."

From the Block of "British Art Online", in the article of "Barbican Center", WeChat user "Wendy Zhu" proposed "the imperial indoor box office is suitable for arranging tickets, stage door is very friendly. I watched a play for the first time here: Richard II."
As for the Block of "British Music", in an article named "Northern Ireland Jazz Musicians: Audio Tape from China", the WeChat user "Heyuke" left the message saying "Britain has many real great jazz, impulse musicians; their music idea and achievements (some creations have applied Chinese culture and element) cannot be matched by these youths; I hope to see these musicians in China."

In the current month recommendation of "Artistic Activity", "Original Edition of Curious Incident Dog Nighttime Come up to the Mysterious World of Youth", WeChat user "Jiaying" pointed out "I always want to go to west London, to listen to the heavy British accent, feel the charm of drama, but I haven't been to England till now. I saw this film in Metro Station several days ago, and I want to ask for my colleagues to watch together with me, not wanting to miss the imported British theater."

Psychologically, motivation is the internal cause and power trigging the behavior, while demand is the base of behavior. The "Use and Satisfaction" theory put forward in the last century regards audiences as an individual with specific demand, and regards intermediary contact behavior as a process of selecting medium according to specific demand to better satisfy their own demands. It can be seen from the analysis of the above six audiences' comments, that two WeChat users indicate they have been to England and share some British culture and self-experience; one user hopes that the British cultural art, especially the elements relating to British music, can have more opportunities to enter into China; one user expresses his love toward British drama, hoping to go to England in person; another two users indicate their affection toward British culture or city. According to the above comments, the audiences, namely the spreading objects, have different interest in various aspects of England, and have certain understanding of England with certain cultural accomplishments. Motivation and demand are mutually related from the perspective of psychology, so it is easy to find through analysis that the motivation of these users paying attention to "UK Now" actually is their thirst and demand for more relevant British information, materially or spiritually.

4) Platform environment: With the advent of digital, interactive and real-time new media, the way people receive and disseminate information has changed. New media, to a certain extent, has become a bridge between communicators and audiences, facilitating the exchange of information between the two. The continuous development of new media such as the Internet and mobile phones, and the popularity of social software such as WeChat and Weibo have brought about changes in communication activities as well as have made it easier to spread activities related to the image of the country.

WeChat public platform, as a functional innovation of WeChat made by Tencent and its R\&D team in August 2012, was a development towards social media. It takes "No matter how small the individual is, it can own its brand." as its advertising slogan, which shows the media attribute of the public platform. The operator of the WeChat public platform can push multiple pieces of information to the audience through the platform, in the forms of image-text, video, or 
voice. According to official statistics of Tencent, as of September 2017, the monthly number of active public platforms is 3.5 million, and the monthly number of active fans is 797 million.

The "Art of the United Kingdom" public platform was registered in February 2015. The first message was pushed on February 9, 2015, in order to inform the establishment of the "Art of the United Kingdom" public platform. Unlike the service platform, which can only send 4 messages a month, the WeChat subscription platform provides a new way for information dissemination for media and individuals. Its main function is to send information to users of WeChat. "Art of the United Kingdom" as a subscription platform, it can send a message a day, which enables it to interact with the users more frequently, and have an advantage in promoting the national image of the United Kingdom. Therefore, "Art of the United Kingdom" as a subscription platform combines the characteristics of the new media, relying on a large amount of users of WeChat and the public platform, can more timely disseminate the cutting edge information of British art and culture, deepen Chinese audience's understanding and memory of Britain, and win more attention and favorability.

\section{ANALYSIS OF NATIONAL IMAGE DISSEMINATION STRATEGY}

\section{A. Different Discourse Perspectives to Help Dissemination}

There are often official and unofficial disseminators of national image. Due to the different nature of the disseminators, their dissemination effects are often different. The thick official color will make the audience feel alert and this type of dissemination often fails to achieve good effect. ${ }^{(8)}$ The "Art of the United Kingdom" public platform is based on the British cultural and educational association which has both unofficial setting and quasi-official nature to spread the image of Britain. Therefore, official and non-official organizations should consider their own characteristics as communicators, their purposes of dissemination, and the effects they want to achieve, and combine with the actual situation to carry out dissemination activities. At the same time, the national image cannot be spread through only one type of media. It should be spread through both official and unofficial media, so the mode of spreading the national image can be more flexible.

\section{B. To Find a Suitable Communication Bridge}

In the process of spreading the national image to foreign countries, due to the different cultural background of the audience and the different cultural dissemination ways, the effect of dissemination is easy to be reduced and even cultural conflicts may be caused. Therefore, it is necessary to find a suitable communication bridge for the spread of national image.

In the process of dissemination, three things are important. The first is to understand the characteristics of the audience's culture. People with different cultural backgrounds have different communication methods and different concerns. Only through in-depth information mining can we better determine the media, content and form of dissemination. The second is to use symbols that the audience can understand. Only when the audience can decode the cognitive symbols can the effectiveness of the whole dissemination activity be guaranteed. The third is to find common ground among the differences. There are different cultures in different countries and different regions. The common ground among the differences is an important factor to promote the exchange of different cultures. The common ground may be the inheritance of cultures or the leading of trends. For example, the " music of Britain" column of the public platform " Art of the United Kingdom" hopes to better integrate British music with Chinese traditional music, continuously innovate and better inherit cultures; the "Women" column of the public platform aims to guide China and England to pay more attention to women's development. Therefore, in the process of spreading the national image, the communication "bridge" is very important. The national image can be better spread if there is a suitable bridge.

\section{To Conduct Multi-angle and Multi-directional Dissemination to Break Cognitive Barriers}

With the continuous development of new media, the modes of dissemination are more diversified and the scope of dissemination is wider. When using the new media to spread the national image from different angles, we should first consider the multiple dimensions that affect the national image. Although the content of the "Art of the United Kingdom" public platform is mainly focused on "art", it involves various dimensions of the national image, including British cultural image, city image, historical image, national quality, government image, etc. Only by creating a unique national image of Britain from different angles can the audience have a more comprehensive understanding of Britain and will the cognitive barriers of the audience be broken. As for the forms of dissemination, online and offline ways are both used. For the online ways, Wechat public platform is used to send multiangle information of the national image to the users. For the offline ways, various activities are held to increase interaction with the audience, and related online reports are used to promote the whole activity or project, helping it win more goodwill and attention, thus further spreading the national image. Under the new media environment, only by conducting multi-angle and multi-directional dissemination of the national image can the disseminators better meet the needs of the audience and can the dissemination better reflect the characteristics of the times.

\section{CONCLUSION}

In short, in the long run, the shaping and dissemination of the national image is a key content that a country needs to pay attention to in its development process. The national image should reflect the national characteristics from various aspects and dimensions. Under the new media environment, the dissemination of the national image should take full account of the characteristics of the object of dissemination, make rational use of emerging media resources, and keep pace with the times. Therefore, how to formulate a reasonable dissemination strategy and improve the reputation of the country is of great strategic significance to the dissemination of the national image. 


\section{REFERENCES}

[1] K.E. Boulding, National Images and International Systems, The Journal of Conflict Resolution,(Vol.3,No2,un 1959),p.120.

[2] Zhang Yuqiang: "Discussion on National Image", "Modern Communication", No. 2 of 2002. 张毓强: 《国家形象刍议》, 《现代传 播》,2002 年第 2 期.

[3] Liu Xiaoyan: “Thinking about the media shaping the national image”, “International Press”, No. 2 of 2002. 刘小燕:《关于传媒塑造国家 形象的思考》，《国际新闻界》,2002 年第 2 期。

[4] Cheng Manli: "Mass Media and National Image Shaping", June 4, 2007 http://media.people.com.cn/GB/40628/5815856.html. 程曼丽: 《大众传 媒与国家形象塑造》, 2007 年 6 月 4 日, http://media.people.com.cn/GB/40628/5815856.html.

[5] Fan Hong. Multi-dimensional shaping and dissemination strategy of national image $[\mathrm{J}]$. Journal of Tsinghua University(Philosophy and Social Sciences),2013,28(02),pp.141-152,p161. 范红.国家形象的多维 塑造与传播策略 [J]. 清华大学学报 (哲学社会科学 版),2013,28(02):141-152+161.

[6] United Kingdom: Cultural Association Annual Report 2012-2013, page 50. 英国:文化协会 2012-2013 年度报告,第 50 页.

[7] Kang Wei. The Principles and Paths for the Creation of Urban Cultural Image $[\mathrm{J}]$. Journal of Shenyang Jianzhu University: Social Science Edition, 2009, 11(02): pp.217-220. 康伟.城市文化形象塑造的原则及 路径[J].沈阳建筑大学学报(社会科学版),2009,11(02):217-220.

[8] Wu Xianju. Cross-cultural generation logic and communication strategy of national image[J]. Academic Journal of Zhongzhou, 2017(05): pp.164-169. 吴献举. 国家形象的跨文化生成逻辑及传播策略 [J].中州 学刊,2017(05):164-169. 